\title{
PERBEDAAN KADAR KOLESTEROL LDL DAN HDL SEBELUM DAN SESUDAH PEMBERIAN JUS KACANG HIJAU (Phaseolus radiatus Linn) PADA PRIA DISLIPIDEMIA
}

\author{
Nur Indah Kartikasari, Ahmad Syauqy ${ }^{*}$ \\ Program Studi Ilmu Gizi Fakultas Kedokteran Universitas Diponegoro \\ Jl.Dr.Sutomo No.18, Semarang, Telp (024) 8453708, Email : gizifk@ undip.ac.id
}

\begin{abstract}
Background : Dyslipidemia has been shown to be one of the risk factors of cardiovascular disease. Mung bean contains of isoflavon, protein, and fiber which is known can reduce LDL-cholesterol level and increase HDLcholesterol level.

Objective : To determine the difference of HDL and LDL-cholesterol levels before and after consumption of mung bean juice.

Methods : This was pre-test and post-test with control group design. Subject were 28 men with serum LDL-cholesterol level 130-189 mg/dl and HDL-cholesterol level $<60 \mathrm{mg} / \mathrm{dl}$. Treatment group consumed mung bean juice 400ml/day and control group consumed packaged drinking water for 21 days. Treatment group and control group were given nutrition counseling before intervention. Serum HDL and LDL-cholesterol levels were measured by phosphotungstic precipitation and Friedewald formula method. Data was analyzed by using Dependent t-test, Independent t-test, Mann Whitney, and Fisher exact.

Results : Consuming mung bean juice 400ml/day during 21 days on treatment group was significantly decrease LDLcholesterol level $(-17,49 \pm 22,61)$ and increase HDL-cholesterol level $(8,87 \pm 5,24)$. On control group, there was not significant decrease of LDL-cholesterol level $(-0,83 \pm 24,30)$ and there was significant increase of HDL-cholesterol level $(2,84 \pm 4,60)$. There was significant difference on the changes of HDL-cholesterol level $(p=0,003)$ between treatment and control group, but there was no difference on the changes of LDL-cholesterol level $(p=0,072)$ between treatment and control group.
\end{abstract}

Conclusion : Consumption of mung bean juice 400ml/day during 21 days was not significantly decrease LDLcholesterol level but was significantly increase HDL-cholesterol level.

Keyword : LDL; HDL; mung bean juice; men; dyslipidemia

\begin{abstract}
ABSTRAK
Latar belakang : Dislipidemia merupakan salah satu faktor risiko dari penyakit kardiovaskuler. Kacang hijau mengandung isoflavon, protein, dan serat yang diketahui dapat menurunkan kadar kolesterol LDL dan meningkatkan kolesterol HDL.

Tujuan : Mengetahui perbedaan kadar kolesterol LDL dan HDL sebelum dan sesudah pemberian jus kacang hijau. Metode : Penelitian ini merupakan pretest - post test with control group design. Subjek adalah 28 pria dengan kadar kolesterol LDL 130-189 mg/dl dan kadar kolesterol HDL $<60$ mg/dl. Kelompok perlakuan mendapatkan jus kacang hijau $400 \mathrm{ml}$ dan kelompok kontrol mendapatkan air minum kemasan selama 21 hari. Kelompok perlakuan dan kelompok kontrol diberikan konseling gizi sebelum intervensi. Kadar kolesterol LDL dan HDL diukur dengan menggunakan metode formula Friedewald dan phosphotungstic precipitation. Data dianalisis menggunakan uji Dependent t-test, Independent t-tes, Mann Whitney, dan Fisher.

Hasil : Pemberian jus kacang hijau $400 \mathrm{ml}$ selama 21 hari pada kelompok perlakuan dapat menurunkan kadar LDL $(-17,49 \pm 22,61)$ dan meningkatkan kadar kolesterol HDL $(8,87 \pm 5,24)$ secara bermakna. Pada kelompok kontrol, terdapat penurunan yang tidak signifikan terhadap kadar kolesterol LDL $(-0,83 \pm 24,30)$ dan terdapat peningkatan

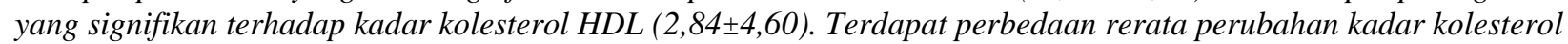
$H D L(p=0,003)$ antara kelompok kontrol dengan kelompok perlakuan, tetapi tidak terdapat perbedaan rerata perubahan kolesterol LDL $(p=0,072)$ antara kelompok kontrol dengan kelompok perlakuan

Simpulan : Pemberian jus kacang hijau 400ml/hari selama 21 hari tidak menurunkan kadar kolesterol LDL secara signifikan, tetapi meningkatkan kadar kolesterol HDL secara signifikan.
\end{abstract}

Kata kunci : LDL; HDL; jus kacang hijau; pria; dislipidemia

\section{PENDAHULUAN}

Penyakit kardiovaskuler merupakan salah satu penyakit kronis yang jumlahnya mencapai 1,5 dari seluruh permasalahan kesehatan global dunia. Diperkirakan pada tahun 2030, 7 dari 10 kematian di seluruh dunia akan disebabkan oleh penyakit kronis, dan penyakit kardiovaskuler menjadi penyebab paling utama. ${ }^{1}$ Salah satu faktor risiko dari penyakit kardiovaskuler adalah dislipidemia. ${ }^{2}$ Penderita dislipidemia mempunyai risiko 2,8 kali lebih besar terkena penyakit jantung koroner. ${ }^{3}$ Dislipidemia adalah gangguan metabolisme

\footnotetext{
${ }^{*}$ Penulis Penanggungjawab
} 
lipoprotein yang dimanifestasikan sebagai salah satu atau beberapa kondisi, seperti peningkatan kolesterol total, kolesterol LDL (Low Density Lipoprotein), trigliserida, atau penurunan kolesterol HDL (High Density Lipoprotein). ${ }^{4,5}$ LDL adalah lipoprotein aterogenik utama dan telah lama diidentifikasi oleh National Cholesterol Education Program (NCEP) sebagai target utama untuk terapi penurunan kolesterol. Sementara itu, seseorang dengan kadar kolesterol LDL yang tinggi dan kadar kolesterol HDL yang rendah lebih berisiko untuk terkena penyakit kardiovaskuler. ${ }^{5}$

Kacang hijau (Phaseolus radiatus L) dikenal sebagai makanan kesehatan yang salah satu manfaatnya berkaitan dengan pengaturan metabolisme lipid. ${ }^{6}$ Dalam 100 gram kacang hijau segar mengandung 70,74 mg isoflavon. ${ }^{7}$ Senyawa isoflavon pada kacang hijau dalam bentuk aglikon berupa daidzein, genistein, dan glisitein. ${ }^{7}$ Isoflavon aglikon dalam bentuk daidzein dan genistein juga ditemukan pada kacang kedelai, di mana pada sebuah penelitian meta - analisis juga menyebutkan bahwa isoflavon kedelai dapat menurunkan kadar kolesterol LDL sebanyak 2,77\%. ${ }^{8}$

Sebuah penelitian dilakukan pada tikus diabetes yang diinduksi alloxan untuk melihat efek ekstrak kacang hijau fermentasi dan nonfermentasi. Hasil dari penelitian tersebut menyatakan bahwa ekstrak kacang hijau fermentasi dan nonfermentasi dapat menyebabkan efek yang lebih baik pada kadar kolesterol LDL tikus. Pada tikus kelompok kontrol, kadar kolesterol LDL menunjukkan angka yang lebih tinggi $(0,40 \pm 0,08)$ daripada tikus yang diberi ekstrak kacang hijau nonfermentasi $(0,27 \pm 0,04)$ walaupun tidak signifikan. Sedangkan efek ekstrak kacang hijau nonfermentasi pada kolesterol HDL pada kelompok perlakuan hasilnya lebih tinggi secara signifikan $(2,70 \pm 0,03)$ daripada kelompok kontrol $(2,49 \pm 0,28) .{ }^{9}$ Pada penelitian yang lain menunjukkan kadar kolesterol HDL tikus wistar jantan yang meningkat setelah pemberian 23,4 gram protein isolat kacang hijau meskipun hasil yang didapatkan juga tidak signifikan. ${ }^{10}$ Dalam 100 gram kacang hijau juga terkandung 7,5 gram serat, di mana diketahui bahwa serat dapat berpengaruh ke kadar kolesterol LDL dan HDL. ${ }^{7,11}$

Berdasarkan uraian di atas, kacang hijau memiliki kandungan zat gizi yang mendukung untuk menurunkan kadar kolesterol LDL dan meningkatkan kadar kolesterol HDL. Pemberian dosis kacang hijau sebanyak 85 gram/hari yang mengandung 41,3 $\mathrm{mg}$ isoflavon ditentukan berdasarkan penelitian yang menyebutkan bahwa isoflavon sebesar $40 \mathrm{mg} / \mathrm{hari}$ dapat menurunkan kadar kolesterol LDL, dan meningkatkan kolesterol
HDL. ${ }^{12,13}$ Pemberian jus kacang hijau dilakukan selama 21 hari (3 minggu) karena menurut penelitian tersebut pemberian isoflavon selama 3 minggu sudah menunjukkan efek yang baik. ${ }^{13}$

Kacang hijau dalam bentuk jus lebih mudah dikonsumsi, selain itu tubuh lebih mudah mengabsorpsi zat gizi dalam bentuk cair daripada bentuk padat. Dalam bentuk jus, ukuran partikel menjadi lebih kecil dan mempermudah proses absorbsi. $^{14}$

Penelitian ini bertujuan untuk mengetahui perbedaan kolesterol LDL dan HDL sebelum dan sesudah pemberian jus kacang hijau pada pria dislipidemia.

\section{METODE PENELITIAN}

Penelitian ini merupakan penelitian true experimental yang menggunakan rancangan pre test - post test with control group design dengan variabel bebas adalah pemberian jus kacang hijau, variabel terikat adalah kolesterol LDL dan HDL, serta asupan makanan dan aktivitas fisik sebagai variabel perancu.

Peneliti telah mendapatkan Ethical Clearance dari Komite Etik Fakultas Kedokteran Universitas Diponegoro. Sebelum penelitian dilaksanakan, subjek juga telah diminta untuk mengisi informed consent sebagai tanda persetujuan mengikuti penelitian. Selain dijelaskan oleh peneliti, keuntungan dan kerugian, serta efek samping yang mungkin ada selama penelitian berlangsung juga telah tertera di materi informed consent. Seluruh data yang berhubungan dengan subjek bersifat pribadi dan hanya digunakan untuk kepentingan penelitian.

Subjek penelitian merupakan karyawan dari beberapa kantor, antara lain kantor Sekretaris Daerah Provinsi Jawa Tengah, karyawan Badan Kepegawaian Daerah, serta karyawan Dinas Sosial, Pemuda, dan Keolahragaan. Kriteria inklusi dari penelitian ini yaitu pria berusia 40 - 58 tahun, kadar kolesterol LDL 130-189 mg/dl dan kadar kolesterol HDL $<60 \mathrm{mg} / \mathrm{dl}$, memiliki indeks massa tubuh $\left(\right.$ IMT) $\geq 23-30 \mathrm{~kg} / \mathrm{m}^{2}$, tidak dalam kondisi sakit atau dalam perawatan dokter berkaitan dengan penyakit diabetes melitus, penyakit jantung koroner, dan penyakit kronis lainnya, tidak sedang mengkonsumsi obat-obatan yang mengendalikan kadar kolesterol darah selama penelitian, merokok tidak lebih dari 10 batang/hari, serta tidak mengkonsumsi alkohol.

Besar sampel yang dibutuhkan dihitung dengan menggunakan rumus uji hipotesis terhadap rerata dua sampel independen, sedangkan pengambilan sampel menggunakan metode consecutive sampling. Sebanyak 68 orang bersedia 
untuk dilakukan pengambilan darah untuk proses skrining awal dan didapatkan 28 orang yang masuk kriteria inklusi. Pembagian kelompok kontrol dan perlakuan dipilih secara simple randomization. Masing - masing kelompok terdiri dari 14 subjek, di mana kelompok perlakuan mendapatkan jus kacang hijau 400ml/hari dan kelompok kontrol mendapatkan air minum kemasan.

Intervensi dilakukan selama 21 hari. Sebelum dilakukan intervensi, subjek pada kelompok kontrol dan kelompok perlakuan diberikan konseling gizi mengenai pola makan yang dianjurkan bagi penderita dislipidemia, kemudian selama intervensi asupan makan masing - masing kelompok dikontrol dan dicatat dengan metode recall 24 jam. Data aktivitas fisik subjek dikumpulkan melalui kuesioner aktivitas fisik Baecke. Kepatuhan subjek dalam mengkonsumsi jus kacang hijau juga dicatat dalam formulir kepatuhan. Pembuatan $400 \mathrm{ml}$ jus kacang hijau menggunakan 85 gram kacang hijau mentah yang direndam selama 8 jam, kemudian direbus selama 20 menit, didiamkan, lalu ditambahkan air $250 \mathrm{ml}$, diblender, dan ditambahkan pemanis buatan.
Pengambilan sampel darah dilakukan oleh petugas laboratorium setelah subjek berpuasa 10 12 jam. Kadar kolesterol LDL dan HDL subjek dianalisis dengan pemeriksaan laboratorium menggunakan metode perhitungan formula Friedewald dan phosphotungstic precipitation. Asupan makanan subjek selama intervensi dianalisis dengan menggunakan program nutrisurvey.

Uji normalitas data dilakukan menggunakan uji Shapiro-Wilk. Perbedaan kadar kolesterol LDL dan HDL sebelum dan sesudah pemberian jus kacang hijau menggunakan uji dependent t-test, sedangkan perbedaan kadar kolesterol LDL dan HDL sebelum dan sesudah intervensi antara kelompok kontrol dengan kelompok perlakuan diuji menggunakan independent t-test.

\section{HASIL PENELITIAN \\ Karakteristik Subjek}

Karakteristik subjek yang terdiri dari gambaran umur, indeks massa tubuh, serta kolesterol LDL dan HDL awal sebelum penelitian disajikan dalam tabel 1, sedangkan gambaran aktivitas fisik disajikan dalam tabel 2 .

Tabel 1. Karakteristik Subjek

\begin{tabular}{lccc}
\hline Variabel & $\begin{array}{c}\text { Perlakuan } \\
(\mathbf{n = 1 4 )}\end{array}$ & $\begin{array}{c}\text { Kontrol } \\
(\mathbf{n = 1 4})\end{array}$ & \multirow{2}{*}{$\mathbf{p}$} \\
\cline { 2 - 3 } & Mean \pm SD & Mean \pm SD & \\
\hline Umur & $49,93 \pm 4,94$ & $49,57 \pm 3,23$ & $0,823^{*}$ \\
Indeks Massa Tubuh & $25,83 \pm 2,16$ & $26,58 \pm 2,24$ & $0,375^{*}$ \\
$23-24,9 \mathrm{~kg} / \mathrm{m}^{2}(n, \%)$ & $4(28,6 \%)$ & $4(28,6 \%)$ & \\
$25-30 \mathrm{~kg} / \mathrm{m}^{2}(n, \%)$ & $10(71,4 \%)$ & $10(71,4 \%)$ & \\
Kolesterol LDL awal & $160,64 \pm 13,96$ & $162,76 \pm 18,26$ & $0,734^{*}$ \\
Kolesterol HDL awal & $31,53 \pm 6,07$ & $36,96 \pm 5,72$ & $0,022^{*}$ \\
\hline
\end{tabular}

*Uji independent t-test

Berdasarkan tabel 1, tidak terdapat perbedaan umur subjek antara kelompok kontrol dan kelompok perlakuan ( $\mathrm{p}>0,05)$. Rata - rata umur subjek pada kelompok kontrol sebesar 49,57 sedangkan pada kelompok perlakuan sebesar 49,93. Kolesterol LDL awal pada kelompok kontrol dengan kelompok perlakuan juga tidak terdapat perbedaan $(p>0,05)$. Namun, terdapat perbedaan kolesterol HDL awal antara kelompok kontrol dengan kelompok perlakuan $(\mathrm{p}<0,05)$. Pada masing - masing kelompok memiliki jumlah subjek yang memiliki status gizi overweight dan obesitas yang sama $(14,3 \%$ dan $35,7 \%)$. Hasil uji t-test juga menunjukkan tidak terdapat perbedaan status gizi antara kelompok kontrol dengan kelompok perlakuan $(\mathrm{p}>0,05)$.

Tabel 2. Gambaran Aktivitas Fisik

\begin{tabular}{|c|c|c|c|c|c|}
\hline \multirow[t]{2}{*}{ Variabel } & \multicolumn{2}{|c|}{$\begin{array}{c}\text { Perlakuan } \\
(n=14)\end{array}$} & \multicolumn{2}{|c|}{$\begin{array}{c}\text { Kontrol } \\
(n=14)\end{array}$} & \multirow[t]{2}{*}{$\mathbf{p}$} \\
\hline & n & $\%$ & $\mathbf{n}$ & $\%$ & \\
\hline \multicolumn{6}{|l|}{ Aktivitas Fisik } \\
\hline Tidak Aktif & 2 & $7,1 \%$ & 1 & $14,3 \%$ & \multirow{2}{*}{$1,000^{*}$} \\
\hline Aktif & 12 & $92,9 \%$ & 13 & $85,7 \%$ & \\
\hline
\end{tabular}

* Uji Fisher 
Aktivitas fisik subjek sebagian besar tergolong aktif. Berdasarkan uji Fisher, tidak terdapat perbedaan aktivitas fisik antara kedua kelompok $(\mathrm{p}>0,05)$.

\section{Asupan Makanan pada Kelompok Kontrol dan Perlakuan}

Tabel 3. Asupan makanan pada kelompok kontrol dan perlakuan

\begin{tabular}{cccc}
\hline \multirow{2}{*}{ Asupan Makanan } & $\begin{array}{c}\text { Perlakuan } \\
(\mathbf{n = 1 4})\end{array}$ & $\begin{array}{c}\text { Kontrol } \\
(\mathbf{n = 1 4})\end{array}$ & $\mathbf{p}$ \\
\cline { 2 - 3 } & Mean \pm SD & Mean \pm SD & $0,838^{*}$ \\
Energi & $1404 \pm 495,53$ & $1371 \pm 349,60$ & $0,818^{* *}$ \\
Protein & $45,31 \pm 17,40$ & $44,76 \pm 13,78$ & $0,351^{*}$ \\
Lemak & $46,61 \pm 18,40$ & $40,51 \pm 15,43$ & $0,491^{* *}$ \\
Karbohidrat & $201,59 \pm 82,19$ & $211,21 \pm 50,54$ & $0,696^{* *}$ \\
Serat & $7,41 \pm 4,48$ & $7,26 \pm 2,14$ & $0,804^{*}$ \\
Kolesterol & $168,56 \pm 98,21$ & $160,66 \pm 64,82$ & \\
\hline
\end{tabular}

*Uji Independent t-test

**Uji Mann Whitney

Berdasarkan tabel 3, tidak terdapat Sedangkan pada kolesterol HDL, terdapat perbedaan asupan energi, protein, lemak, karbohidrat, serat, dan kolesterol antara kelompok kontrol dengan kelompok perlakuan $(p>0,05)$.

Pengaruh Pemberian Jus Kacang Hijau terhadap Kadar Kolesterol LDL dan HDL

Pada akhir penelitian dapat dinyatakan bahwa terdapat perbedaan kadar kolesterol LDL sebelum dan sesudah intervensi pada kelompok perlakuan $(p<0,05)$ dan tidak terdapat perbedaan kadar kolesterol LDL sebelum dan sesudah perbedaan sebelum dan sesudah intervensi baik pada kelompok kontrol maupun perlakuan. Perbedaan rerata perubahan kadar kolesterol LDL dan HDL antar kedua kelompok dianalisis menggunakan uji independent t-test. Tidak terdapat perbedaan rerata perubahan pada kadar kolesterol LDL $(p>0,05)$ tetapi terdapat perbedaan rerata perubahan pada kadar kolesterol HDL $(p<0,05)$ antara kelompok kontrol dengan kelompok perlakuan.

intervensi pada kelompok kontrol $(\mathrm{p}>0,05)$.

Tabel 4. Pengaruh Pemberian Jus Kacang Hijau terhadap Kadar Kolesterol LDL dan HDL

\begin{tabular}{lccc}
\hline \multicolumn{1}{c}{ Variabel } & $\begin{array}{c}\text { Perlakuan } \\
(\mathbf{n = 1 4})\end{array}$ & $\begin{array}{c}\text { Kontrol } \\
(\mathbf{n = 1 4})\end{array}$ & \multirow{2}{*}{$\mathbf{p}^{* *}$} \\
\cline { 2 - 3 } & Mean \pm SD & Mean \pm SD & \\
\hline Kolestrol LDL (mg/dl) & & & \\
Awal & $160,64 \pm 13,96$ & $162,76 \pm 18,26$ \\
Akhir & $143,16 \pm 16,30$ & $161,93 \pm 28,50$ & \\
$\Delta$ & $-17,49 \pm 22,61$ & $-0,83 \pm 24,30$ & 0,072 \\
p* & 0,013 & 0,900 & \\
Kolestrol HDL (mg/dl) & & & \\
Awal & $31,53 \pm 6,07$ & $36,96 \pm 5,72$ & \\
Akhir & $40,40 \pm 8,25$ & $39,80 \pm 4,30$ & 0,003 \\
$\Delta$ & $8,87 \pm 5,24$ & $2,84 \pm 4,60$ & \\
p* & 0,000 & 0,038 & \\
\hline
\end{tabular}

*Uji Dependent t-test

**Uji Independent t-test

\section{Kepatuhan Konsumsi Jus Kacang Hijau}

Jus kacang hijau sebanyak $400 \mathrm{ml}$ diberikan kepada subjek selama 21 hari pada pukul 10.00 WIB. Berdasarkan formulir kepatuhan, terdapat dua subjek yang menyisakan $25 \%$ jus kacang hijau sebanyak dua kali dan terdapat satu subjek yang menyisakan jus kacang hijau 25\% sebanyak satu kali. Selain ketiga subjek tersebut, seluruh subjek menghabiskan jus kacang hijau 100\% selama 21 hari.

Ketiga subjek tersebut tidak menghabiskan jus kacang hijau karena subjek merasa cepat kenyang setelah minum jus kacang hijau sehingga tidak mengkonsumsi jus kacang hijau sampai habis. 


\section{PEMBAHASAN}

Karakteristik subjek dalam penelitian ini adalah pria dengan kadar kolesterol LDL 130-189 $\mathrm{mg} / \mathrm{dl}$ dan kadar kolesterol HDL $<60 \mathrm{mg} / \mathrm{dl}$. Tidak terdapat perbedaan umur dan indeks massa tubuh antara kelompok kontrol dengan kelompok perlakuan. Aktivitas fisik subjek juga sebagian besar tergolong aktif. Namun, kadar kolesterol HDL awal antara kelompok kontrol dan kelompok perlakuan ditemukan adanya perbedaan secara statistik. Hal ini dapat disebabkan karena rentang rata - rata kolesterol HDL awal antara kelompok kontrol dan kelompok perlakuan cukup jauh $(36,96 \pm 5,72$ dan $31,53 \pm 6,07)$ walaupun telah dilakukan simple randomization.

Pria dengan usia $\geq 40$ tahun memiliki risiko dislipidemia yang lebih besar. ${ }^{15} \mathrm{Hal}$ ini disebabkan semakin tua usia seseorang berkaitan dengan perubahan kontrol endotel pada relaksasi pembuluh darah vaskuler dan elastisitas pembuluh darah arteri yang mengakibatkan adanya aterosklerosis yang lebih banyak. ${ }^{16}$ Status gizi yang tidak normal, dalam hal ini overweight dan obesitas juga berperan sebagai faktor risiko dislipidemia. ${ }^{15}$ Dalam penelitian ini diketahui bahwa asupan energi, protein, lemak, karbohidrat, serat, dan kolesterol pada kedua kelompok subjek tidak ada perbedaan ( $\mathrm{p}$ $>0,05)$.

Pada penelitian ini, pemberian $400 \mathrm{ml}$ jus kacang hijau selama 21 hari menghasilkan penurunan secara bermakna terhadap kadar kolesterol LDL pada subjek sebelum dan sesudah intervensi $(\mathrm{p}<0,05)$ tetapi tidak terdapat perbedaan kadar kolesterol LDL antara kelompok kontrol dengan kelompok perlakuan $(p>0,05)$. Sementara itu terdapat peningkatan secara bermakna kadar kolesterol HDL sebelum dan sesudah pemberian jus kacang hijau $(\mathrm{p}<0,05)$ serta terdapat perbedaan kadar kolesterol HDL antara kelompok kontrol dengan kelompok perlakuan $(\mathrm{p}<0,05)$.

Penurunan kadar kolesterol LDL dan peningkatan kadar kolesterol HDL pada subjek sebelum dan sesudah pemberian jus kacang hijau membuktikan bahwa jus kacang hijau berpengaruh terhadap kadar kolesterol LDL dan HDL. Rata-rata penurunan kadar kolesterol LDL sebesar 17.49 $\mathrm{mg} / \mathrm{dl}$. Sedangkan pada kadar kolesterol HDL ratarata peningkatannya sebesar $8.87 \mathrm{mg} / \mathrm{dl}$.

Hal ini sesuai dengan studi sebelumnya yang menyatakan bahwa ekstrak kacang hijau fermentasi dan nonfermentasi dapat menyebabkan efek yang lebih baik pada kadar kolesterol LDL tikus. Pada tikus kelompok kontrol, kadar kolesterol LDL menunjukkan angka yang lebih tinggi $(0,40 \pm$ $0,08)$ daripada tikus yang diberi ekstrak kacang hijau nonfermentasi $(0,27 \pm 0,04)$ walaupun tidak signifikan. Sedangkan efek ekstrak kacang hijau nonfermentasi pada kolesterol HDL pada kelompok perlakuan hasilnya lebih tinggi secara signifikan $(2,70 \pm 0,03)$ daripada kelompok kontrol $(2,49 \pm$ 0,28). ${ }^{10}$ Bedanya, dalam penelitian jus kacang hijau ini memberikan hasil yang signifikan pada kedua variabel kolesterol.

Penurunan kadar kolesterol LDL dan peningkatan kadar kolesterol HDL yang lebih besar pada kelompok perlakuan dibandingkan kelompok kontrol disebabkan karena kelompok perlakuan mengkonsumsi jus kacang hijau $400 \mathrm{ml}$ selama 21 hari sedangkan kelompok kontrol tidak mengkonsumsi jus kacang hijau. Penurunan kadar kolesterol LDL dan peningkatan kolesterol HDL tersebut disebabkan adanya isoflavon aglikon pada kacang hijau. Isoflavon pada kacang hijau adalah dari daidzein, genistein, dan glisitein yang sama dengan isoflavon yang terkandung dalam kacang kedelai. Pada sebuah penelitian meta - analisis juga menyebutkan bahwa isoflavon kedelai dapat menurunkan kadar kolesterol LDL sebanyak $2,77 \% .^{7,8}$ Isoflavon bersifat antioksidan, dapat menurunkan kadar kolesterol LDL dan melindungi dari oksidasi. Secara in vivo, isoflavon mampu mencegah oksidasi LDL sehingga tidak terbentuk ateroma pada dinding arteri. Penghambatan migrasi dan proliferasi sel otot polos yang dilakukan isoflavon mempunyai peran dalam promosi dan progresi aterosklerosis. ${ }^{17}$ Genistein dan daidzein dalam isoflavon juga dapat meningkatkan sekresi apoA-I dari sel hati, di mana ApoA-I merupakan komponen utama dari HDL sehingga kolesterol HDL meningkat. ${ }^{18,19}$

Serat yang terkandung dalam kacang hijau juga dapat menjadi penyebab penurunan kadar kolesterol LDL. Konsumsi serat akan meningkatkan ekskresi garam empedu dan kolesterol melalui feses maka garam empedu yang mengalami siklus enterohepatik juga berkurang. Berkurangnya garam empedu yang masuk ke hati dan berkurangnya absorpsi kolesterol akan menurunkan kadar kolesterol sel hati. Ini akan meningkatkan pengambilan kolesterol dari darah yang akan dipakai untuk sintesis garam empedu yang baru yang akibatnya akan menurunkan kadar kolesterol darah. $^{20}$ Sedangkan mekanisme serat dalam meningkatkan kadar kolesterol HDL belum dapat dijelaskan secara pasti, namun diduga melalui pengikatan asam empedu dan kolesterol yang secara tidak langsung merangsang sintesis HDL di dalam hati. ${ }^{21}$

Peningkatan kadar kolesterol HDL juga dapat disebabkan oleh adanya kandungan protein 
pada kacang hijau. Terdapat penelitian lain yang membandingkan pengaruh antara tikus wistar jantan yang diberi casein bebas vitamin dan isolat protein kacang hijau. Hasilnya yaitu tikus yang diberi isolat protein kacang hijau kadar kolesterol HDL pada tikus yang diberi isolat protein kacang hijau menunjukkan angka yang lebih tinggi $(48,8 \pm 1,80)$ daripada tikus yang diberi casein bebas vitamin $(45,6 \pm 5,0)$ walaupun hasilnya tidak signifikan. Peningkatan kadar kolesterol HDL tersebut dapat disebabkan oleh adiponektin yang meningkat pada tikus yang diberi isolat protein kacang hijau. ${ }^{9}$ Adiponektin diketahui dapat meningkatkan kadar kolesterol HDL melalui peningkatan jalur ABCA1 dan sintesis ApoA-I. ${ }^{22}$ Adiponektin juga menghambat ekspresi scavenger receptor class A-1 (SR-A) makrofag sehingga menyebabkan penurunan pengambilan LDL yang teroksidasi dan menghambat pembentukan sel busa (foam cell). ${ }^{23}$

Kadar kolesterol LDL dan HDL pada kelompok perlakuan meskipun mengalami peningkatan dan penurunan, tetapi kadar kolesterol LDL subjek masih ada yang tergolong tinggi dan kadar kolesterol HDL subjek masih ada yang tergolong rendah. Padahal jika dilihat dari asupan, asupan subjek masih termasuk kurang dari kebutuhan yang dianjurkan. Asupan kolesterol subjek juga masih dalam batas normal $<200$ $\mathrm{mg} /$ hari sesuai dengan yang dianjurkan oleh American Heart Journal dan Therapy Lowering Cholesterol (TLC) diet. ${ }^{24}$ Kemungkinan ini terjadi karena status gizi subjek yang tergolong overweight dan obesitas dan telah dialami dalam waktu yang cukup lama. Seseorang dengan obesitas dapat menyebabkan resistensi insulin yang berimbas ke produksi VLDL yang berlebihan sehingga aktivitas reseptor LDL berkurang dan kadar kolesterol LDL meningkat. ${ }^{25}$ Resistensi insulin juga berdampak langsung terhadap metabolisme HDL. Ketika jaringan adiposa membesar dan insulin menjadi lebih resisten, kemudian diinfiltrasi dengan makrofag yang membuat peradangan. Sitokin terlepas ke jaringan adiposa yang mengakibatkan penurunan pengaturan beberapa protein transport kolesterol, termasuk ABCA1, ABCG1, dan SR-BI, yang menurunkan pembentukan HDL. ${ }^{26}$

Pada kedua kelompok, diketahui rata - rata asupan subjek masih kurang dari kebutuhan. Kurangnya asupan dari kebutuhan kemungkinan karena sebelum penelitian telah dilakukan konseling gizi sehingga subjek membatasi asupannya. Kemungkinan lainnya karena subjek merasa jenuh akibat dari dilakukan recall setiap hari selama 21 hari. Beberapa penelitian menunjukkan bahwa minimal 2 kali recall 24 jam tanpa berturut - turut dapat memberikan gambaran asupan zat gizi lebih optimal dan memberikan variasi yang lebih besar tentang asupan harian individu. ${ }^{27}$

Pada kelompok kontrol, kadar kolesterol LDL dan kadar kolesterol HDL sama - sama mengalami penurunan dan peningkatan. Hal ini kemungkinan disebabkan oleh adanya peningkatan aktivitas fisik pada kelompok kontrol. Namun karena pengambilan data aktivitas fisik hanya dilakukan pada awal penelitian sehingga tidak diketahui apakah terjadi peningkatan aktivitas fisik. Aktivitas fisik berupa olahraga dan kegiatan harian yang dilakukan secara rutin dapat meningkatkan konsentrasi HDL kolesterol dan bermanfaat untuk mencegah timbunan lemak / kolesterol (terutama kolesterol LDL) di dinding pembuluh darah (arterosklerosis). ${ }^{28}$ Penelitian yang dilakukan di poliklinik jantung RSUD Dr Moewardi Surakarta juga menunjukkan hasil bahwa sebesar 76,92\% subjek penelitian yang tingkat aktivitasnya tergolong tinggi memiliki rasio total kolesterol/HDL baik. ${ }^{29}$ Penurunan kadar kolesterol LDL dan peningkatan kadar kolesterol HDL pada kelompok perlakuan juga kemungkinan disebabkan oleh adanya pemberian konseling gizi sebelum penelitian sehingga subjek lebih menjaga pola makan dan gaya hidup. Tetapi pada kelompok perlakuan terjadi penurunan kadar kolesterol LDL dan peningkatan kadar kolesterol HDL yang lebih besar karena pemberian jus kacang hijau. Sedangkan antara kelompok kontrol dan kelompok perlakuan tidak terdapat perbedaan perubahan rerata kadar kolesterol LDL kemungkinan karena standar deviasi pada kedua kelompok sama - sama besar walaupun rata - rata perbedaan kadar kolesterol LDL pada kelompok perlakuan lebih besar.

\section{SIMPULAN}

Berdasarkan analisis hasil penelitian dapat disimpulkan bahwa pemberian jus kacang hijau 400 ml selama 21 hari tidak membuktikan penurunan kadar kolesterol LDL secara bermakna, tetapi meningkatkan kadar kolesterol HDL secara bermakna.

\section{SARAN}

Pengambilan data asupan makanan melalui recall 24 jam sebaiknya tidak dilakukan setiap hari (minimal 2 kali tidak berturut - turut dalam hari biasa dan hari libur) untuk menghindari subjek merasa jenuh saat dilakukan recall sehingga menghasilkan data asupan makanan yang lebih valid. 


\section{DAFTAR PUSTAKA}

1. Paradis G, Chiolero A. The cardiovascular and chronic diseases epidemic in low- and middleincome countries. JACC. 2011;57(17).

2. Yusuf S, Hawken S, Ounpuu S, Dans T, Avezum A, Lanas F, et al. INTERHEART Study Investigators. Effect of potentially modifiable risk factors associated with $\mathrm{mi}$ in 52 countries (the INTERHEART study): case-control study. Lancet. 2004;364:937-52.

3. Supriyono, M. Faktor-Faktor Risiko yang Berpengaruh Terhadap Kejadian Penyakit Jantung Koroner pada Kelompok Usia < 45 Tahun [tesis]. Program Pasca Sarjana - Magister Epidemiologi. Universitas Diponegoro.2008.

4. Anonim. Essence Series : Dyslipidemia. Cipla. 2005.

5. Chronic Disease Management and Prevention Network. Building healthy lifestyle vascular protection dyslipidemia clinical guide. Chinook Health Region. 2006.

6. Tang D, Dong Y, Ren H, Li L, He C. A review of phytochemistry, metabolite changes, and medicinal uses of the common food mung bean and its sprouts (Vigna radiata). Chemistry Central Journal. 2014;8:4.

7. Iswandari R. Studi kandungan isoflavon pada kacang hijau, tempe kacang hijau, dan bubur kacang hijau. Karya Tulis Ilmiah. Institut Pertanian Bogor. 2008.

8. Taku K, Umegaki K, Ishimi Y, Watanabe S. Soy isoflavones lower serum total and LDL cholesterol in humans: a meta-analysis of 11 randomized controlled trials. Am J Clin Nutr. 2007;85:1148 56.

9. Tachibana N, Wanezaki S, Nagata M, Motoyama T, Kohmo M, Kitagawa S. Intake of mung bean protein isolate reduces plasma triglyceride levelin rats. Functional Foods in Health and Disease. 2013;3(9):365-76.

10. Yeap SK, Ali NM, Yusof HM, Alitheen NB, Beh BK, Ho WY, et al. Antihyperglycemic effects of fermented and nonfermented mung bean extracts on alloxan-induced-diabetic mice. Hindawi Publishing Corporation Journal of Biomedicine and Biotechnology. 2012.

11. Fujii H, Iwase M, Ohkuma T, Kaizu SO, Ide H, Kikuchi Y, et al. Impact of dietary fiber intake on glycemic control, cardiovascular risk factors and chronic kidney disease in Japanese patients with type 2 diabetes mellitus: the Fukuoka diabetes registry. Nutrition Journal. 2013;12:159.

12. JB Howes, D Sullivan, N Lai, P Nestel, S Pomeroy, L West et all. The effects of dietary supplementation with isoflavones from red clover on the lipoprotein profiles of post menopausal women with mild to moderate hypercholesterolaemia. Elsevier. 2000. P.143-147.
13. Zhan S, C Ho Suzanne. Meta-analysis of the effects of soy protein containing isoflavones on the lipid profile. Am J Clin Nutr. 2005;81:397-408.

14. Agdeppa, IA. Nutrients in vegetable juice easily absorbed by the body. Food and Nutrition Research Institute. 2006.

15. Grundy SM, Becker D, Clark LT, Cooper RS, Denke MA, Howard WJ, et al. National cholesterol education program : Detection, evaluation, and treatment of high blood cholesterol in adults (Adult Treatment Panel III). National Institute of Health. 2001.

16. Jellinger PS, Smith DA, Mehta AE, Ganda O, Handelsman Y, Rodbard HW, et al. American association of clinical endrocrinologists guidelines for management of dyslipidemia and prevention of atherosclerosis. Endocrine Practice. 2012;18 (Suppl 1).

17. Michihiro, S. Soy in health and disease prevention. New York : Taylor and Francis Group. 2006.

18. Lamon-Fava, S. Genistein activates apolipoprotein A-I gene expression in the human hepatoma cell line hep G2. American Society for Nutritional Sciences. 2000.

19. Adam JMF. Dislipidemia. Dalam : Sudoyo AW, Setiyohadi B, Alwi I, Simadibrata KA, Setiyati S, editors. Buku Ajar Ilmu Penyakit Dalam. Jakarta : Fakultas Kedokteran UI;2006.h.1926-1932.

20. Tala, ZZ. Manfaat serat bagi kesehatan. Departemen Ilmu Gizi Fakultas Kedokteran Universitas Sumatera Utara. 2009.

21. Nelwan G, Wullur AC, Bodhi W. Pengaruh jus buah apel merah (Pyrus malus L.) terhadap kadar kolesterol HDL (High Density Lipoprotein) darah tikus putih jantan galur wistar (Rattus norvegicus). Program Studi Farmasi FMIPA UNSRAT Manado. 2012.

22. Matsuura F, Oku H, Koseki M, Sandoval JC, Kawase MY, Yamamoto KT, et al. Adiponectin accelerates reverse cholesterol transport by increasing high density lipoprotein assembly in the liver. Biochemical and Biophysical Research Communications. 2007;358:1091-95.

23. Matsuzawa Y, Funahashi T, Kihara S, Shimomura I. Adyponectin and metabolic syndrome. Arterioscler Thromb Vasc Biol. 2004;24:29-33

24. Raymond JL, Couch SC. Medical nutrition therapy for cardiovascular disease. In : Mahan LK, EscottStump S, Raymond JL. Krause's food and the nutrition care process 13th edition. Elsevier. 2012.

25. Widiastuti, E. Perbedaan kadar LDL-kolesterol metoda direk dengan formula friedewald (Pada penderita diabetes melitus). Program Pendidikan Dokter Spesialis Bagian Patologi Klinik FK UNDIP. 2003.

26. Bays HE, Toth PP, Khris-Etherton PM, Abate N, Aronne LJ, Brown WV, et al. Obesity, adiposity, and dyslipidemia : A consensus statement from the National Lipid Association. Journal of Clinical Lipidology. 2013;7(4):304-383. 
27. Supariasa IDN, Bakri B, Fajar I. Penilaian status gizi. Jakarta : Penerbit Buku Kedokteran EGC. 2002.

28. Soeharto, I. Serangan jantung dan stroke hubungannya dengan lemak dan kolestrol. Jakarta: PT. Gramedia Pustaka Utama. 2004.

29. Rahmawati AC, Zulaekah S, Rahmawaty S. Aktivitas fisik dan rasio kolesterol (HDL) pada penderita penyakit jantung koroner di poliklinik jantung RSUD Dr Moewardi Surakarta. Jurnal Kesehatan. 2009;2:11-18. 